\title{
Thyroid Hormone levels in Highlanders- A Comparison Be- tween Residents of Two Altitudes in Nepal
}

\author{
Nepal O, ${ }^{1}$ Pokhrel BR, ${ }^{1}$ Khanal K, ${ }^{2}$ Gyawali P, ${ }^{3}$ Malik SL, ${ }^{1}$ Koju R, ${ }^{4}$ Kapoor BK ${ }^{1}$
}

${ }^{1}$ Department of Physiology

${ }^{2}$ Department of Community Medicine

${ }^{3}$ Department of Clinical Biochemistry

${ }^{4}$ Department of Internal Medicine

Dhulikhel Hospital-Kathmandu University Hospital Kathmandu University School of Medical Sciences Dhulikhel, Kavre, Nepal

\section{Corresponding Author}

Ojashwi Nepal

Department of Physiology

Dhulikhel Hospital-Kathmandu University Hospital Kathmandu University School of Medical Sciences Dhulikhel, Kavre, Nepal

Email: ojan2nep@gmail.com

\section{Citation}

Nepal O, Pokhrel BR, Khanal K, Gyawali P, Malik SL Koju $R$ et.al. Thyroid Hormone levels in HighlandersA Comparison Between Residents of Two Altitudes in Nepal. Kathmandu Univ Med J 2013;41(1):18-21 .

\begin{abstract}
Background

The endocrine changes related to altitude adaptation in human have attracted physiologists around the globe for long. A number of high altitude studies to detect the physiological changes have been performed now and then. But, the study to see the hormonal changes to compare populations residing at different high altitudes is a scarce. Hence, we have performed a study in native populations of different high altitude comparing changes in thyroid hormones in western Nepal. The Jharkot population included in this study is at altitude of $3760 \mathrm{~m}$ and Jomsom population at $2800 \mathrm{~m}$ height from sea bed.
\end{abstract}

\section{Objective}

The study is to compare changes in thyroid hormones at two different high altitude natives.

\section{Methods}

To compare thyroid status between high altitude natives at two different altitudes a cross sectional study is performed by random sampling method. The blood sample was collected in a vacutainer from fifty eight individuals after obtaining the informed consent of participants. The blood collected from antecubital vein was centrifuged in an hour and the serum obtained was used for biochemical analysis of free triiodothyronine, free thyroxine and thyroid stimulating hormone.

\section{Results}

Mean free thyroxine $\left(\mathrm{fT}_{4}\right)$ of Jharkot population is significantly larger $(p=0.001)$ than Jomsom population. Mean thyroid stimulating hormone (TSH) with $p=$ 0.597 , does not indicate the difference between this two population. There is no significant difference between mean free triiodothyronine $\left(\mathrm{fT}_{3}\right)$ of Jharkot and Jomsom population $(p=0.345)$.

\section{Conclusion}

The rise in free thyroid hormone at high altitude is not dependent on the thyroid stimulating hormone released from anterior pituitary. The rise in free thyroxine is found at higher altitude and no difference in $\mathrm{fT}_{3}$ level is detected in population studied at high altitudes.

\section{KEY WORDS}

Free triiodothyronine, free thyroxine, TSH, high altitude, $t$-test 


\section{INTRODUCTION}

The rise in the plasma $\mathrm{T}_{4}$ requires activation of hypothalamopituitary-thyroid axis in healthy individuals but, the elevation of $\mathrm{T}_{4}$ independent of TSH has been reported at high altitude..$^{1-3}$

An intact hypothalamic-pituitary-thyroid axis is well established by 12-16 weeks of gestation. Production of $T_{3}$ and $T_{4}$ in the thyroid gland is stimulated by thyrotrophin (thyroid-stimulating hormone, TSH), a glycoprotein released from the thyrotroph cells of the anterior pituitary in response to the hypothalamic tripeptide, thyrotrophinreleasing hormone. Thyroid hormone regulates metabolic processes in most organs and is different from many hormones for its stability in response to environmental signals. $^{4}$

Field studies at moderate or high altitude have shown conflicting results regarding level of thyroid hormones which can be due to difficulty in standardization of field studies. ${ }^{5}$ Many factors such as wind, temperature, radiation and others, may affect certain endocrine parameters, but they cannot be individually quantified. Since, thyroid hormone is related to mental development and cognition and psychic stress is known to influence the hypothalamopituitary-thyroid/adrenal axis, the fluctuation in thyroid hormone seen at high altitude has been attempted to explain with respect to psychological performance in few studies conducted in the past. ${ }^{6-8}$

High altitude residence is known to modify body biochemistry and hormone status. ${ }^{9}$

In this study we have attempted to compare the thyroid hormones status in high altitude natives residing at two different altitudes from sea bed.

\section{METHODS}

The study was conducted from $15^{\text {th }} \mathrm{Nov}-15^{\text {th }}$ Dec of 2010. The population studied was from two different altitudes at $2800 \mathrm{~m}$ and $3760 \mathrm{~m}$ of Mustang district of western Nepal. The lower altitude natives $(2800 \mathrm{~m})$ belonged to Jomsom and the higher altitude $(3760 \mathrm{~m})$ were residents of Jharkot. The volunteers subjected to study were fifty eight in number, of which thirty three were from Jomsom and twenty five were natives of Jharkot. Fifty eight subjects aged between 12-75 years, participated voluntarily in the study.

The subjects included in the study were selected randomly from the native population who visited health post for their regular health examination. Healthy volunteers were included in the study after obtaining the history and general clinical examination Individuals on medications and patients suffering from chronic diseases like hypertension, diabetes and pulmonary diseases were excluded from the study.
The sample blood was drawn from the antecubital vein in the vacutainer by the aseptic technique after the written consent from all participants. The $3 \mathrm{ml}$ blood collected from each individual was centrifuged and serum was stored for the analysis of thyroid hormones and thyroid stimulating hormone.

Thyroid hormones level at different altitudes of two different populations was compared using t-test. Data were entered on MS Excel and SPSS version 16 was used to analyze them.

\section{RESULT}

The status of thyroid hormones in these high altitude populations was significantly different.

Though sample size in Jomsom population is thirty three, the result for TSH of a subject was not available after biochemical analysis; therefore, thirty two subjects were studied. As in table 1, there is no significant difference between mean $\left(\mathrm{fT}_{3}\right)$ of Jharkot and Jomsom population $(p=0.345)$. There is significant difference between mean value of $\mathrm{fT}_{4}$ between two population- Jomsom and Jharkot $(p=0.002)$ as depicted in table 2. Mean $\mathrm{fT}_{4}$ of Jharkot population is significantly larger than Jomsom population ( $p=0.001$ ) but mean thyroid stimulating hormone (TSH) does not differ significantly between two population ( $p=$ 0.597), shown in table 3.

Table 1. $\mathrm{fT}_{3}$ comparison between Jomsom and Jharkot population.

\begin{tabular}{|llllll|}
\hline \multicolumn{5}{|c}{} & \multicolumn{5}{c}{ Group Statistics } \\
V Study Area & $\mathbf{N}$ & Mean & $\begin{array}{l}\text { Std. Devia- } \\
\text { tion }\end{array}$ & $\begin{array}{l}\text { Std. Error } \\
\text { Mean }\end{array}$ \\
\hline Jomsom & 33 & 2.3721 & .84301 & .14675 \\
\hline Jharkot & 25 & 2.5624 & .61456 & .12291 \\
\hline
\end{tabular}

There is no significant difference between mean fT3 value of Jomsom and Jharkot population ( $p=0.345)$.

Table 2. fT4 comparison between Jomsom and Jharkot population.

\begin{tabular}{|llllll}
\hline & \multicolumn{5}{c}{ Group Statistics } \\
Study Area & $\mathbf{N}$ & Mean & $\begin{array}{l}\text { Std. Devia- } \\
\text { tion }\end{array}$ & $\begin{array}{l}\text { Std. Error } \\
\text { Mean }\end{array}$ \\
\multirow{2}{*}{ Value } & Jomsom & 33 & 1.3191 & .24002 & .04178 \\
& Jharkot & 25 & 1.5476 & .26932 & .05386
\end{tabular}

There is significant difference between mean $\mathrm{ft} 4$ value of Jomsom and Jharkot population $\left(p=0.002\right.$ ) and mean $\mathrm{fT}_{4}$ of Jharkot population is significantly larger than Jomsom population $(p=0.001)$.

The normal range of $\mathrm{fT}_{4}=0.8-2.0 \mathrm{ng} / \mathrm{dl}_{1} \mathrm{fT}_{3}=1.4-4.2$ $\mathrm{pg} / \mathrm{ml}$ and $\mathrm{TSH}=0.39-6.16 \mu \mathrm{lU} / \mathrm{ml} \mathrm{fT}_{3^{\prime}}, \mathrm{fT}_{4}$ and $\mathrm{TSH}$ was measured by ELISA technique (ELISCAN, RFCL, India). Normally, in the healthy adult free $T_{3}$ found in the blood is converted from free $T_{4}$ at peripheral tissues like liver and kidney. 
Table 3. TSH comparison between Jomsom and Jharkot population.

\begin{tabular}{|c|c|c|c|c|c|}
\hline \multicolumn{6}{|c|}{ Group Statistics } \\
\hline \multirow{3}{*}{ Value } & Study Area & $\mathbf{N}$ & Mean & $\begin{array}{l}\text { Std. Devia- } \\
\text { tion }\end{array}$ & $\begin{array}{l}\text { Std. Error } \\
\text { Mean }\end{array}$ \\
\hline & Jomsom & 32 & 2.8656 & 2.92090 & .51635 \\
\hline & Jharkot & 25 & 2.4672 & 2.65959 & .53192 \\
\hline
\end{tabular}

There is no significant difference of mean TSH value between Jomsom and Jharkot population $(p=0.597)$.

\section{DISCUSSION}

Thyroid hormone synthesis and secretion by the thyroid gland follows a negative feedback mechanism to keep the normal concentration of plasma $T_{3}$ and $T_{4}$. Both of these hormones are bound to plasma proteins albumin and globulin respectively. However, more $\mathrm{T}_{4}$ is bound to plasma protein than $T_{3}$. The free forms of these two hormones diffuse through cell membrane.

The active form of thyroid hormone is $T_{3}$ and is derived from $T_{4}$ intracellular after $T_{4}$ diffuse into the cell. The rise in the plasma thyroid hormones at high altitude without the rise in TSH has been reported. ${ }^{10}$ However, considering the classic feedback mechanism operating physiologically, rise in the thyroid hormones require a thyroid stimulating hormone action over the thyroid gland. ${ }^{11}$

In the recent study, the finding of rise in free $\mathrm{T}_{4}$ without a rise in TSH at higher altitude compared to lower high altitude is consistent with previous studies. ${ }^{2,3,5,12}$ However the decrease in free $T_{3}$ has been reported with the rise in free $T_{4}$ at high altitude. ${ }^{2}$ The total plasma $T_{4}$ level is higher than total plasma $T_{3}$ as the secretion of thyroxine is greater than triiododthyronine by thyroid gland. The estimation of total thyroid hormones can be misleading because acquired and congenital variations in the concentrations of binding proteins exist between individuals, and it is the free thyroid hormones in plasma that are physiologically active and that feedback to inhibit pituitary secretion of $\mathrm{TSH}^{13}{ }^{13}$ Therefore, to observe the change in free thyroid hormones we have analysed $\mathrm{fT}_{3}$ and $\mathrm{fT}_{4}$ in our study. Here, the rise in $\mathrm{fT}_{4}$ without rise in TSH at higher altitude could be an indication of lesser binding of $\mathrm{T}_{4}$ to thyroxine binding globulin so as to provide conversion of more $\mathrm{fT}_{4}$ to $f T_{3}$. However, a study in an expedition to climb Mt. McKinley, $\mathrm{AK}$ has shown less $\mathrm{fT}_{3}$ conversion from $\mathrm{fT}_{4}$ due to cortisol rise in the plasma. ${ }^{14}$ The cortisol rise can be due to stress in those who attempt expedition, where as the local natives at high altitude may not have rise in cortisol, hence does not impair the conversion to $\mathrm{fT}_{3}$ from $\mathrm{fT}_{4}$.

Further, stable mean thyroid stimulating hormone (TSH) in both altitude populations signifies the independent rise of serum $\mathrm{fT}_{3}$ and $\mathrm{fT}_{4}$. The rise in thyroid hormone levels independent of pituitary secretion of thyrotropin has been reported and favors the recent finding. ${ }^{3,15}$

The finding of significantly larger $\mathrm{fT}_{4}$ in these natives independent of TSH, rationalizes that TSH estimation in high altitude natives can be useful for pathological diagnosis of hypo or hyperthyroidism in the light of physiologically altered $\mathrm{fT}_{4}$. The altered free thyroid hormones can be the adaptive feature of high altitude natives and should be considered clinically while investigating for thyroid pathology.

The study performed to compare the changes in two different altitude natives does not consider the possible changes in parameters like reverse $T_{3}$, thyroxine binding globulin, albumin, transthyretin and cortisol. Total $T_{3}$ and total $T_{4}$ estimation though ignored in our study, if performed could have been reliable comparator for in depth understanding of fluctuations in binding, and conversion of thyroid hormones.

In order to explore the changes in endocrine system and its effect in metabolism and psychology at high altitude natives, endocrinological parameters related to hypothalamo-hypophysial-target gland axis needs to be further studied in these populations.

\section{CONCLUSION}

Higher altitude population has greater $\mathrm{fT}_{4}$ independent of pituitary secretion of thyrotropin. There is no difference detected in $\mathrm{fT}_{3}$ level between both the populations studied.

\section{ACHNOWLEDGEMENT}

We gratefully acknowledge the help extended by the Department of Clinical Biochemistry for the biochemical analysis of thyroid hormones in the midst of busy schedule.

\section{REFERENCES}

1. Barnholt KE, Hoffman AR, Rock PB, Muza SR, Fulco CS, Braun B et al. Endocrine responses to acute and chronic high-altitude exposure (4,300 meters): modulating effects of caloric restriction. Am J Physiol 2006; 290(6):1078-88.

2. Benso A, Broglio F, Aimaretti G, Lucatello B, Lanfranco F, Ghigo E et al. Endocrine and metabolic responses to extreme altitude and physical exercise in climbers. Eur J Endocrinol 2007; 157(6):733-40.

3. Sawhney RC, Malhotra AS. Thyroid function in sojourners and acclimatised low landers at high altitude in man. Horm Metab Res 1991; 23(2):81-4.

4. Richalet J-P, Letournel $M$, Souberbielle J-C. Effects of high-altitude hypoxia on the hormonal response to hypothalamic factors. Am J Physiol 2010; 299(6):1685-92.

5. West JB. Best and Taylor's Physiological Basis of Medical Practice. 12th ed. Baltimore: Williams \& Wilkins; 1991.

6. Basu M, Pal K, Malhotra AS, Prasad R, Sawhney RC. Free and total thyroid hormones in humans at extreme altitude. Int I Biometeorol 1995; 39(1):17-21.

7. Dimai HP, Ramschak-Schwarzer S, Leb G. Altitude hypoxia: effects on selected endocrinological parameters. Wien Med Wochenschr [Internet]. 2000 Jan [cited 2012 Jun 9]; 150(8-9):178-81. Available from: http://www.ncbi.nlm.nih.gov/pubmed/10960959. 
8. Vander AJ, Sherman JH, Luciano DS. Human Physiology: The mechanism of body function. 8th ed. Boston, MA: McGraw-Hill; 2001.

9. Palinkas LA, Reedy KR, Shepanek M, Smith M, Anghel M, Steel GD et al. Environmental influences on hypothalamic-pituitary-thyroid function and behavior in Antarctica. Physiol Behav 2007; 92(5):790-9.

10. Sachidhanandam M, Arumugam S, Ray US. Thyroid hormone changes and psychological response to high altitude stress: effect of ethnicity. Presented at Society for Endocrinology BES 2011, Birmingham, UK. Endocrine Abstracts 25 P344. Available from: http://www.endocrineabstracts.org/ea/0025/ea0025p344.htm.

11. Querido A, Bleichrodt N, Djokomoeljanto R. Thyroid Hormones and Human Mental Development. Prog Brain Res 1978; 48:337-46.
12. Barrett KE, Barman SM, Boitano S, Brooks HL. Ganong's Review of Medical Physiology. 23rd ed. United States: McGraw-Hill; 2010.

13. Hackney AC, Feith S, Pozos R, Seale J. Effects of high altitude and cold exposure on resting thyroid hormone concentrations. Aviat Space Environ Med 1995; 66(4):325-9.

14. Ramirez G, Herrera R, Pineda D, Bittle PA, Rabb HA, Bercu BB. The effects of high altitude on hypothalamic-pituitary secretory dynamics in men. Clin endocrinol 1995; 43(1):11-8.

15. Savourey G, Garcia N, Caravel JP, Gharib C, Pouzeratte N, Martin S. Pre-adaptation, adaptation and de-adaptation to high altitude in humans: hormonal and biochemical changes at sea level. Eur J Appl Physiol 1997; 77(1-2):37-43. 